\title{
Estudio técnico de la decoración del techo perteneciente a la Sala Capitular del Ayuntamiento de Sevilla
}

\section{Seville City Hall Chapter Room ceiling decoration}

\author{
A. Durán ${ }^{(*, * * *)}$, Ma. D. Robador(**), M. C. Jiménez de Haro(*), L. K. Herrera(*), P. Gimena ${ }^{(* *)}$, \\ J. L. Pérez-Rodríguez ${ }^{(*)}$
}

Recepción/Received: 29-XI-07

Aceptación/Accepted: 3-III-08

Publicado online/Online publishing: 9-II-10

\section{RESUMEN}

El objetivo de este trabajo es el estudio de diferentes aspectos, como el color, la composición química y las fases mineralógicas presentes en los diferentes materiales que forman la ornamentación del techo de la Sala Capitular del Ayuntamiento de Sevilla, mediante métodos físicos y químicos. Nuestros resultados muestran que el dorado fue realizado sobre una capa de bol previamente depositada sobre una lámina de blanco de plomo que cubría un estrato de calcita. Posteriormente, y probablemente debido a alteraciones en el dorado original, el techo fue de nuevo dorado usando una técnica similar. En el siglo XIX, casi todo el techo, excepto las zonas con inscripciones, fue blanqueado usando una mezcla de calcita y blanco de plomo. Se empleó plata para cubrir la espada del rey Juan I (casetón 27). Finísimas láminas de oro se usaron para decorar los atributos reales: coronas, cinturones, cetros, espadas y rosarios. En diferentes partes de la decoración fueron detectados pigmentos como azurita, malaquita, bermellón y negro de humo. La composición del mortero de la estructura era a base de cal y dolomita molida.

Palabras clave: dorado, pigmentos, piedra, mortero, color.

\section{SUMMARY}

The present article describes a chemical and physical study of the colour, chemical composition and mineral phases of the decorative materials in the Seville City Hall Chapter House ceiling. The findings showed that the inner most layer of material, calcite, was covered with white lead, in turn concealed under a layer of gilded bole. The ceiling underwent re-gilding, also over bole, due in all likelihood to wear on the original gold leaf. In the nineteenth century, the entire ceiling with the exception of the inscriptions was whitewashed with calcite and white lead. Silver was employed on King John I's sword (coffer 27). Gold leaf was used to adorn the royal attributes: crowns, belts, sceptres, swords and rosary beads. The high reliefs were likewise gilded. The pigments identified on the ceiling adornments included azurite, malachite, vermilion and gas black. A lime and ground dolomite mortar was used throughout.

Keywords: gilding, pigments, stone, mortar, colour.

(*) Instituto de Ciencia de Materiales de Sevilla (CSIC-Universidad de Sevilla) (Sevilla, España).

(**) Universidad de Sevilla (Sevilla, España).

(***) European Radiation Synchrotron Facility (ESRF), Grenoble CEDEX (Francia). 


\section{INTRODUCCIÓN}

El Ayuntamiento de Sevilla es un magnífico edificio renacentista (1527-1564) con un frente oriental muy decorado, que constituye uno de los ejemplos con más encanto del estilo Plateresco. El edificio contiene en su interior valiosos cuadros de Zurbarán y otros artistas. La construcción del edificio se inició siguiendo el proyecto de Diego de Riaño, que fue "maestro oficial" de las obras hasta noviembre de 1534. El término Plateresco (1) se ha generalizado a partir de mediados del siglo $\mathrm{XX}$, ya que fue utilizado por la crítica moderna para describir obras de arte concretas $y$, por extensión, a toda la arquitectura española construida en la primera mitad del siglo XVI. La Sala Capitular, el centro gubernamental de Sevilla durante 450 años, es una construcción moderna y prodigiosa, resultado de la implantación de las corrientes humanísticas y del desarrollo político y económico de la época (2).

La Sala Capitular, de planta rectangular con dimensiones 10,94 x 8,27 m, está cubierta por una bóveda en carpanel muy rebajado formada por nervaduras que definen una retícula ortogonal, que es rematada por cruceros revirados, es decir, verticales. En los casetones, se han esculpido en piedra treinta y seis reyes de Castilla y León, que reinaron entre 866 y 1566, quedando de esta forma inmortalizados. La piedra que se usó en la construcción de la bóveda es una biocalcarenita. La decoración en piedra consistía en dorados y policromías de diferentes colores realizadas por Antonio Vázquez y Miguel Vallés. El proceso de decoración de la Sala concluyó en el año 1572 (3).

La Sala Capitular necesitaba una restauración y reconstrucción completas para proteger este edificio histórico. La Casa Consistorial y el Patronato del Real Alcázar solicitaron un estudio científico sobre los materiales usados en la decoración de esta Sala, que sirva como referencia para tomar las decisiones en la restauración. El objetivo de esta investigación es el estudio de todos los componentes que forman parte de la decoración del techo de la Sala Capitular del Ayuntamiento de Sevilla. Los resultados obtenidos sirvieron para llevar a cabo la restauración de los elementos arquitectónicos de este importante edificio.

\section{MATERIALES Y MÉTODOS EXPERIMENTALES}

Se tomaron veintitrés muestras del techo de la Sala Capitular (Figura 1a). La descripción y localización de cada muestra se indican en la Tabla I.

La caracterización cromática se hizo in situ usando un espectrómetro portátil marca DRLANGE NEURTEK modelo LMC3/DIAM5. Para la medición del color, se usó una

\section{INTRODUCTION}

Seville City Hall is a superb Renaissance building (152764) whose richly decorated east facade is a handsome example of Plateresque architecture. The building is home to a number of valuable paintings by Zurbarán and other artists. The early phases of construction conformed to the design authored by Diego de Riaño, master builder for the works through November 1534. The use of the term "Plateresque" (1) became generally accepted beginning in the mid-twentieth century. After having originally been used by modern art historians to describe specific works of art, it was later extended to refer to all sixteenth century Spanish architecture. The Chapter House, the centre of municipal governance for 450 years, is a signal monument with many modern features, a result of the convergence of humanism and the political and economic development of the times (2).

This rectangular room $(10.94 \times 8.27 \mathrm{~m})$ is roofed by a lowered basket-handle vault. Its ribs form a right-angled lattice extended downward by thin, criss-crossed stone slabs. Thirty six kings who reigned in Castile and Leon from 866 to 1566 have been immortalized in stone sculptures in the resulting coffers. The vault was built with biocalcarenite stone whose adornments were gilded and polychromed by Antonio Vázquez and Miguel Vallés. Decoration was completed on the Chapter House in 1572 (3).

Inasmuch as the room was in need of thorough restoration and reconstruction, Seville's municipal government and Reales Alcazares commissioned a scientific analysis of the decorative materials that would serve as a guide during restoration. The present article is a report on all the components of the Chapter House ceiling decoration. Its findings were used to restore the architectural elements of this monumental building.

\section{MATERIALS AND EXPERIMENTAL}

Twenty three samples were taken from the Chapter Room ceiling (Figure 1a). The description and location of each are given in Table $I$.

A DRLANGE NEURTEK LMC3/DIAM5 portable spectrometer was used for field chromatic analysis. Colour measurements were taken under a xenon lamp 


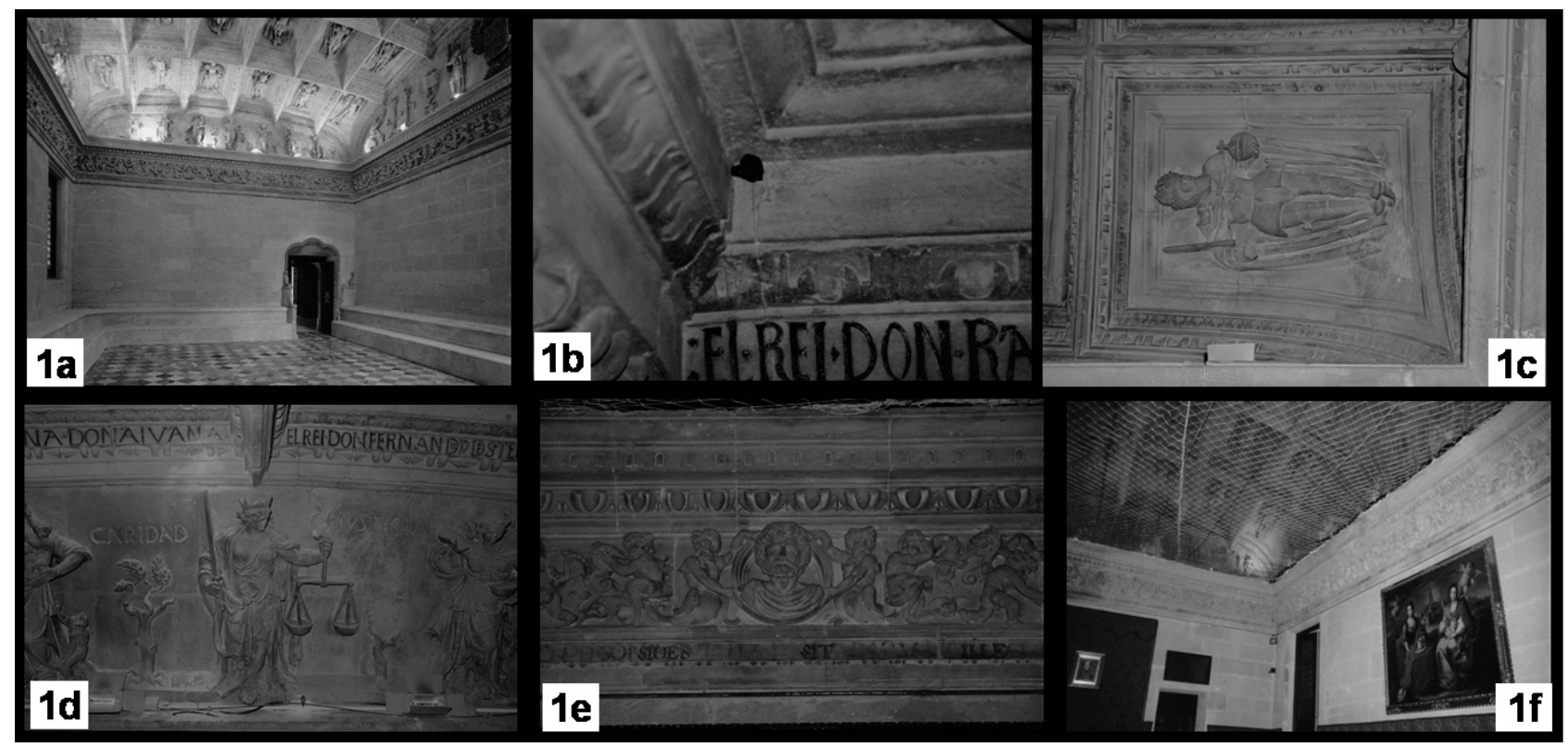

Figura 1. Fotografías: a) Vista general de la Sala Capitular; b) Decoración vegetal del casetón número 33, con inscripciones de color negro; c) Ornamentación del casetón 41, con inscripciones doradas; d) Ornamentación correspondiente a "La Justicia", con inscripciones de color negro; e) Ornamentación del friso, con inscripciones doradas y de color negro; f) Vista de la red usada como protección por debajo del techo.

Figure 1. Photographs: a) overview of the Chapter House; b) plant-like decoration in coffer 33, with black inscriptions; c) adornment in coffer 41, with gilded inscriptions; d) sculpture depicting "Justice", with black inscriptions; e) frieze decorated with black and gilded inscriptions; f) protective net hung under the ceiling.

lámpara de xenón, que produce luz normalizada D65. Este instrumento midió valores de tres variables (tri-estímulos) en coordenadas CIEL*a*b* sobre las superficies examinadas. El espacio $L^{*} a * b *$ fue definido como un espacio uniforme de color por la CIE (Comission International de l'Eclaraige). Las mediciones se realizaron por triplicado y en las tablas se muestran los valores medios de dichas medidas con sus valores de desviación estándar.

Las estratigrafías se prepararon siguiendo la metodología de Khandekar (4), Wachowiak (5) y Herrera y col. (6).

La observación de las estratigrafías se hizo empleando un microscopio Nikon HOPTIHOT con objetivos x20, x50, x100 y x200 (luz reflejada), que está equipado con una cámara digital Nikon COOLPIX 4500 para hacer fotomicrografías. Se eligieron algunas muestras y se hizo la identificación de la secuencia estratigráfica de la misma (las escalas se muestran en las imágenes de las diferentes muestras) (7-10).

Los compuestos cristalinos fueron caracterizados por difracción de rayos $X$, utilizando un difractómetro Siemens, modelo kristalloflex D-5000, que usa radiación $\mathrm{Cu}$ $\mathrm{K} \alpha(40 \mathrm{kV}, 30 \mathrm{~mA})$, monocromador de grafito y detector de centelleo. Las medidas se llevaron a cabo con muestras en polvo en el rango $3^{\circ}<2 \Theta<65^{\circ}$ con un paso de $0,05^{\circ}$ y 2 segundos por paso. Seguidamente, se empleó la base estándar de datos cristalinos del EVA para la identificación de fases $(11,12)$. emitting standard D65 light. This instrument measured three variables of the surface studied to determine the CIEL*a*b* colour coordinates. The CIE (Commission internationale de l'Éclairage) has defined $L^{*} a * b^{*}$ space to be an area with uniform colour. The values given in the tables are the mean of three measurements and are shown with their respective standard deviations.

The cross-sections of the samples were prepared as described by Khandekar (4) Wachowiak (5) and Herrera et al. (6).

They were observed under a Nikon HOPTIHOT reflected light microscope fitted with 20x, 50x, 100x and 200x (reflected light) lenses and a Nikon COOLPIX 4500 digital camera to take microphotographs. Certain of the samples were selected to identify their stratigraphic sequences (the scale is shown on the photographs in Figure 2) (7-10).

The crystalline compounds were characterized with a Siemens Kristalloflex D-5000 X-ray diffractor, using 40 $k V, 30 \mathrm{~mA} \mathrm{Cu}-\mathrm{K \alpha}$ radiation, a graphite monochromator and a scintillation detector. Measurements were taken on powdery samples in a $2 \Theta$ range of $3^{\circ}-65^{\circ}$, with a step size of $0.05^{\circ}$ at a rate of 2 seconds per step. EVA software was used to identify the crystalline phases (11, 12). 
Tabla 1 / Table 1

Descripción y localización de las muestras.

Sample description and location.

\begin{tabular}{|c|c|c|}
\hline Muestra / Sample & Descripción / Description & Localización / Location \\
\hline 1 & $\begin{array}{l}\text { Recubrimiento dorado de la decoración vegetal de la nervadura / } \\
\text { Gilding on plants decorating vault rib }\end{array}$ & $\begin{array}{l}\text { Casetón número } 15 \text { del Rey Alfonso VII / } \\
\text { Coffer } 15 \text { King Alfonse VII }\end{array}$ \\
\hline 2 & Decoración vegetal / Plant adornments & $\begin{array}{c}\text { Casetón número } 33 \text { de la Reina Juana I de Castilla / } \\
\text { Coffer 33, Queen Jane of Castile }\end{array}$ \\
\hline 3 & Recubrimiento dorado del cetro / Gilding on sceptre & Casetón número 33 / Coffer 33 \\
\hline 4 & $\begin{array}{c}\text { Recubrimiento azul, naranja y dorado de las hojas vegetales / } \\
\text { Blue and orange pigment, gilding on plant leaves }\end{array}$ & Casetón número 33 / Coffer 33 \\
\hline 5 & $\begin{array}{l}\text { Recubrimiento azul verdoso detrás de las hojas vegetales / } \\
\text { Blue-green pigment behind plant leaves }\end{array}$ & Casetón número 33 / Coffer 33 \\
\hline 6 & $\begin{array}{l}\text { Recubrimiento verde de hojas de la nervadura / } \\
\text { Green pigmento on plant leaves on rib }\end{array}$ & Casetón número 33 / Coffer 33 \\
\hline 7 & Recubrimiento dorado de la corona / Gilding on crown & Casetón número 33 / Coffer 33 \\
\hline 8 & Recubrimiento plateado de la espada / Silver plating on sword & Casetón número 27 del Rey Juan I / Coffer 27 King John I \\
\hline 9 & Recubrimiento de color rojo / Red pigment & Bóveda / Vault \\
\hline 10 & $\begin{array}{l}\text { Recubrimiento de color rojo y dorado / } \\
\text { Red pigment and gilding }\end{array}$ & Bóveda / Vault \\
\hline 11 & Dorado / Gilding & Bóveda / Vault \\
\hline 12 & Dorado / Gilding & Bóveda / Vault \\
\hline 13 & $\begin{array}{l}\text { Muestra de color dorado y púrpura / } \\
\text { Purple pigment and gilding }\end{array}$ & Bóveda / Vault \\
\hline 14 & Decoración de color oscuro / Dark pigment & Bóveda / Vault \\
\hline 15 & & $\begin{array}{l}\text { Escultura de la Justicia en el Friso Norte / } \\
\text { Sculpture of Justice on North Frieze }\end{array}$ \\
\hline 16 & Color negro de la escritura / Black inscription & Casetón número 10 del Rey Ramiro / Coffer 10 King Ramiro \\
\hline 17 & $\begin{array}{l}\text { Colores dorado y negro de la escritura / } \\
\text { Black and gilded inscriptions }\end{array}$ & Contorno de la cornisa / Edge around cornice \\
\hline 18 & Escritura de color dorado / Gilded inscription & Friso por debajo del escudo / Frieze under heraldic shield \\
\hline 19 & Piedra desprendida de la bóveda / Stone detached from vault & Recogida de la red de protección / Protective netting \\
\hline 20 & Piedra desprendida de la bóveda / Stone detached from vault & Recogida de la red de protección / Protective netting \\
\hline 21 & Material desprendido / Detached material & Casetón número 23 del Rey Enrique I / Coffer 23 King Henry I \\
\hline 22 & Mortero / Mortar & Casetón número 21 del Rey Alfonso X / Coffer 21 King Alfonse $X$ \\
\hline
\end{tabular}

Las microfotografías de microscopía electrónica de barrido se obtuvieron con un microscopio Jeol JSM5400. El análisis químico elemental semicuantitativo en los diferentes estratos se obtuvo con el espectrómetro de energías dispersivas de rayos $X$ Link ISIS, equipado con una ventana de berilio ultrafina, y empleando un voltaje de $20 \mathrm{keV}$. Las estratigrafías se cubrieron con capas de carbón para realizar el estudio por MEB/EDX (13).

La espectroscopía infrarroja por transformada de Fourier (FT-IR) (equipo Nicolet 510) se empleó para determinar tanto los compuestos inorgánicos como los orgánicos presentes. La mayoría de las muestras se molieron y prepararon en pastillas con $\mathrm{KBr}$ (bromuro potásico) (5 mg de muestra en $100 \mathrm{mg}$ de $\mathrm{KBr}$ ) con el método estándar para la preparación de muestras para los estudios por espectroscopía de infrarrojos. Se aplicaron 8 toneladas de presión para la elaboración de pastillas transparentes de $\mathrm{KBr}$. Este método de preparación incluye la molienda de la muestra para la preparación de las pastillas de KBr,
The scanning electronic micrographs were taken with a Jeol JSM5400 microscope. Semi-quantitative elemental chemical analysis of the various layers was obtained with a Link ISIS energy dispersive $X$-ray spectrometer fitted with an ultrathin beryllium window, operating at a voltage of $20 \mathrm{KeV}$. The samples were carbon-coated for the SEM/EDX study (13).

The presence of both organic and inorganic compounds was determined with a Nicolet 510 Fourier transform infrared (FTIR) spectroscope. Most of the samples were ground and compressed into potassium bromide pellets ( $5 \mathrm{mg}$ of sample in $100 \mathrm{mg}$ of $\mathrm{KBr}$ ), the standard procedure for preparing samples for infrared spectroscopic analysis. The transparent $\mathrm{KBr}$ pellets were compressed under a force of eight tonnes. This method entails grinding the sample included in the $\mathrm{KBr}$ pellets to prevent light dispersion. Peak positions were determined with Nicolet Omnic 
lo que previene la dispersión de la luz. Las posiciones de los picos se determinaron mediante el software Nicolet Omnic (basado en un método polinomial de mínimos cuadrados) (14-16).

\section{RESULTADOS Y DISCUSIÓN}

\subsection{Muestras con oro}

La estratigrafía de la muestra 1 se expone en la Figura $2 a$. Siete estratos se observan en la misma. El análisis elemental indica la presencia de $\mathrm{Ca}$, Si y pequeñas cantidades de $\mathrm{Al}, \mathrm{O}$ y $\mathrm{K}$ en el estrato de color blanco situado en la parte inferior de la muestra (Figura 3a). El estudio por espectroscopía de infrarrojos muestra la presencia de carbonatos (bandas a $1.461 \mathrm{~cm}^{-1}$ y $874 \mathrm{~cm}^{-1}$ ) y silicatos (banda a $1.050 \mathrm{~cm}^{-1}$ ) en este estrato (Figura 4a). Estos resultados se atribuyen a la presencia de calcita y silicatos. Encima de éste, se aplicó un segundo estrato de color blanco, que contiene principalmente $\mathrm{Pb}, \mathrm{O}$ y $\mathrm{C}$ (análisis EDX, Figura $3 \mathrm{~b}$ ) y carbonatos (estudio por espectroscopía de infrarrojos, banda a $1.401 \mathrm{~cm}^{-1}$, Figura 4b). Estos datos concuerdan con la presencia de blanco de plomo en dicho estrato. Sobre este último aparece un estrato de color marrón, cuyos análisis muestran la presencia de $\mathrm{Fe}, \mathrm{Si}, \mathrm{y}$ además, pequeñas cantidades de $\mathrm{Pb}, \mathrm{O}$ y $\mathrm{C}$ (Figura $3 \mathrm{c}$ ), que se justifican con la presencia de bol (mezcla de óxidos de hierro y silicatos) y de algo de blanco de plomo, éste procedente probablemente de la capa o estrato inferior. El bol fue empleado para depositar sobre él una lámina de oro (Figura 3d). Encima de este dorado, se encontró otro estrato de color marrón, cuya composición software (based on the minimum squares method) (14-16).

\section{RESULTS AND DISCUSSION}

\subsection{Samples containing gold}

The cross-section for sample 1 shown in Figure 2a had seven layers. Elemental analysis detected the presence of Ca, Si and smaller quantities of $A l, O$ and $K$ in the white layer at the bottom of the sample (Figure 3a). The infrared spectroscopic study showed that it also contained carbonates (bands at $1461 \mathrm{~cm}^{-1}$ and $874 \mathrm{~cm}^{-1}$ ) and silicates (band at $1050 \mathrm{~cm}^{-1}$ ) (Figure 4a). These findings were attributed to the presence of calcite and silicates. The second white layer applied on top of this first stratum contained primarily $P b, O$ and $C$ (EDX analysis, Figure $3 b$ ) and carbonates (IR spectroscopy, band at $1401 \mathrm{~cm}^{-1}$, Figure 4b). These findings are consistent with the presence of white lead in that layer. The next higher layer was brown and contained, according to the analyses, $\mathrm{Fe}, \mathrm{Si}$ and small amounts of $\mathrm{Pb}, \mathrm{O}$ and $\mathrm{C}$ (Figure $3 \mathrm{c}$ ), which would indicate the existence of a layer of bole (a mix of iron oxides and silicate) with some white lead, probably from the layer below. Bole was used as a substrate for the gold leaf (Figure 3d). This gilding was buried underneath another layer of brown material containing white lead, iron oxides and silicate, likewise gilded (analysis not shown). Lastly, further to the IR spectroscopic and EDX studies, the topmost, whitish layer comprised calcite and white

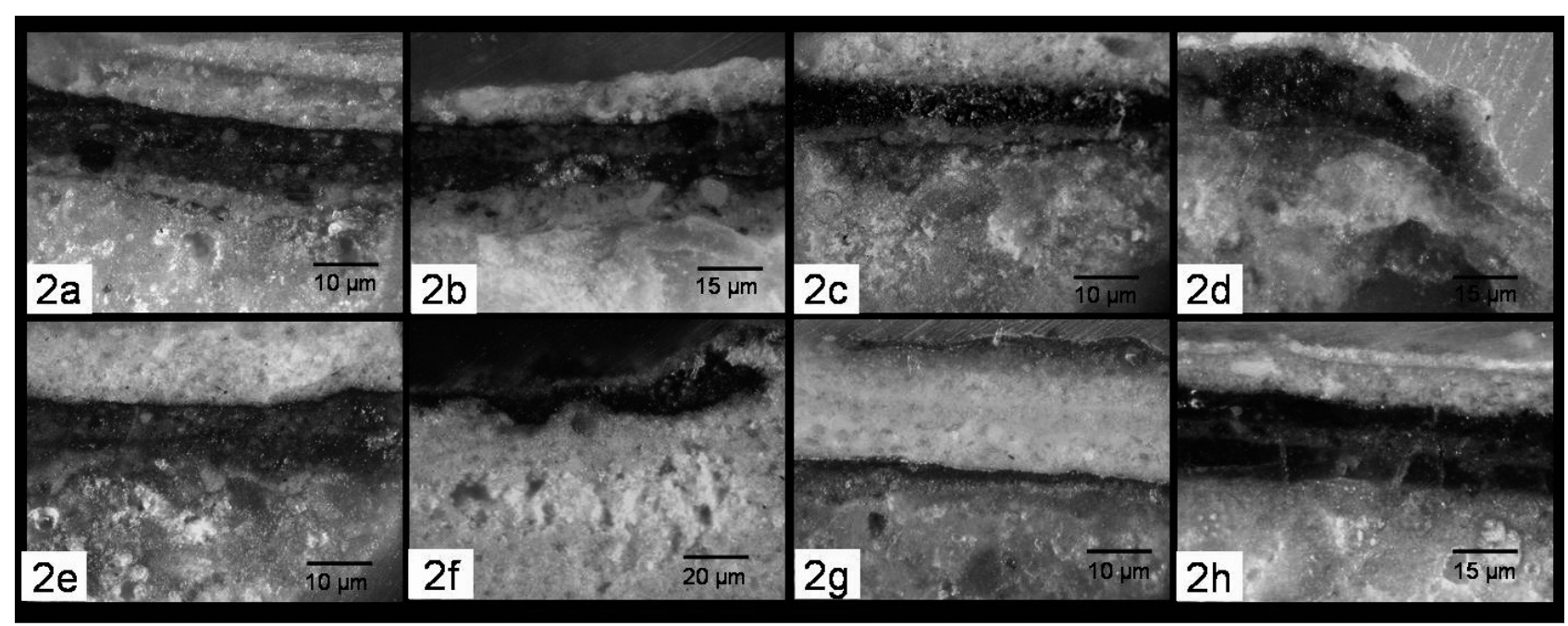

Figura 2. Fotografías de estratigrafías correspondientes a: a) muestra 1 (muestra dorada); b) muestra 3 (muestra dorada); c) muestra 4 (muestra de color azul); d) muestra 6 (muestra de color verde); e) muestra 8 (muestra "dorada" con plata); f) muestra 16 (muestra con inscripciones de color negro); g) muestra 17 (muestra con inscripciones doradas); h) muestra 9.

Figure 2. Cross-sections of: a) sample 1 (gilding); b) sample 3 (gilding); c) sample 4 (blue); d) sample 6 (green); e) sample 8 (silver "gilding"); f) sample 16 (black inscriptions); $g$ ) sample 17 (gilded inscriptions; $h$ ) sample 9. 
estaba basada en una mezcla de blanco de plomo, óxidos de hierro y silicatos, apareciendo encima de él, de nuevo una lámina de oro (Análisis no mostrado). Por último, se detecta otro estrato de color blanco compuesto por calcita y blanco de plomo, y óxidos de hierro y silicatos en baja proporción, de acuerdo con los estudios por espectroscopía de infrarrojos y EDX (Figura 3e, mediante EDX, se detectaron $\mathrm{Ca}, \mathrm{Pb}, \mathrm{Si}$, Fe y O) (espectro de IR con bandas de carbonatos a $1.419 \mathrm{~cm}^{-1}$ y 874 $\mathrm{cm}^{-1}$, y de silicatos a $1.038 \mathrm{~cm}^{-1}$, Figura 4c). Todos estos datos indican que la muestra del techo objeto de estudio se doró dos veces y, más tarde, se pintó con una mezcla formada por cal, blanco de plomo y óxidos de hierro. Probablemente, el óxido de hierro se usó para obtener un tono de color similar al de la piedra. Una descripción similar ha sido descrita por Robador (17).

La composición de la muestra 2 (Figura no mostrada) es similar a la descrita anteriormente -muestra $1-$. Sin embargo, yeso en pequeña proporción aparece en la capa superficial, que fue atribuido a la presencia de contaminación medioambiental external (Figura 3f, EDX, presencia de $\mathrm{Ca}, \mathrm{S}, \mathrm{Pb}, \mathrm{C}$ y O) (Figura 4d, espectro de IR, banda de sulfatos a $\left.1.169 \mathrm{~cm}^{-1}\right)$.

El diagrama de difracción de rayos $\mathrm{X}$ de la muestra completa (Figura 5a) confirma la presencia de calcita (C), blanco de plomo (hidrocerusita, Hy, y cerusita, Cer), oro (Au) y yeso (Gy).

Los análisis de la estratigrafía de la muestra 3 (Figura 2b) indican una composición muy similar a las muestras 1 y 2 , pero en este caso, la segunda lámina de oro no se encontró. lead, small proportions of iron oxides and silicates (EDX, Figure 3e, revealed $\mathrm{Ca}, \mathrm{Pb}, \mathrm{Si}$, Fe and O) (IR, Figure 4C, showed carbonate bands at $1419 \mathrm{~cm}^{-1}$ and $874 \mathrm{~cm}^{-1}$, and silicate signals at $1038 \mathrm{~cm}^{-1}$ ). The foregoing indicated that the sample of ceiling studied was gilded twice and later painted with a mix of lime, white lead and iron oxides. The iron oxide was used, in all likelihood, to attain a colour that would blend with the stone. Robador (17) has reported similar findings.

The composition found for sample 2 (not shown) closely resembled the results for sample 1 , except that it contained gypsum in the outermost layer, attributed to exposure to the environment (Figure 3f, EDX, presence of $\mathrm{Ca}, \mathrm{S}, \mathrm{Pb}, \mathrm{C}$ and $\mathrm{O}$ ) (Figure $4 d, I R$ spectrum, sulfate band at $1169 \mathrm{~cm}^{-1}$ ).

The X-ray diffraction pattern for the entire sample (Figure 5a) confirmed the presence of calcite (C), white lead (hydrocerussite, $\mathrm{Hy}$ and cerussite Cer), gold (Au) and gypsum (Gy).

The analyses of sample 3 (Figure $2 b$ ) showed that it was similar in composition to samples 1 and 2, but it was lacking the second layer of gilding.

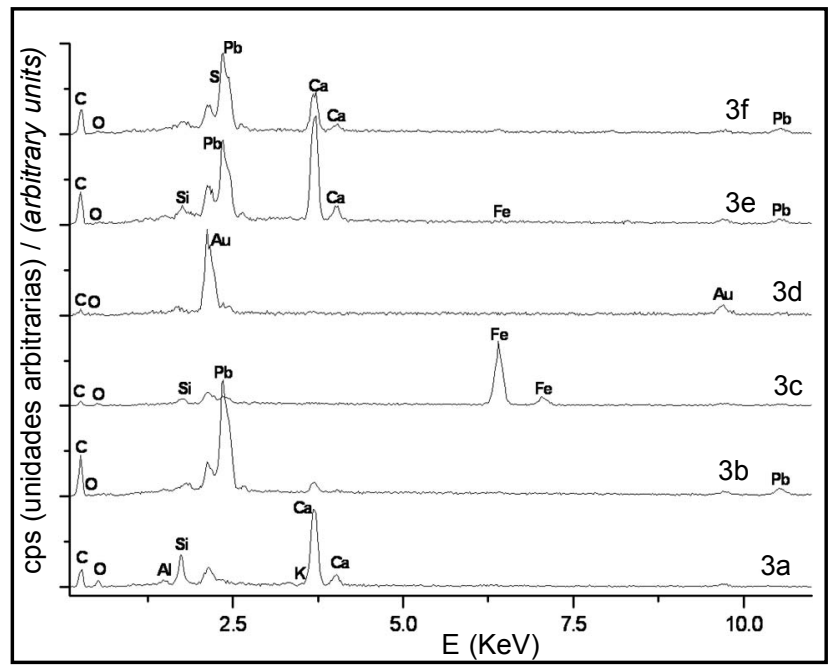

Figura 3. a), b), c), d), e) Análisis por energías dispersivas de rayos $X$ correspondientes a los diferentes estratos de la muestra 2. f) Análisis por energías dispersivas de rayos $X$ de la capa superficial de la muestra 2.

Figure 3. a), b) c), d), e) Energy dispersive $X$-ray analysis of the different layers in sample 2. f) Energy dispersive $X$-ray analysis of the outermost layer in sample 2. 


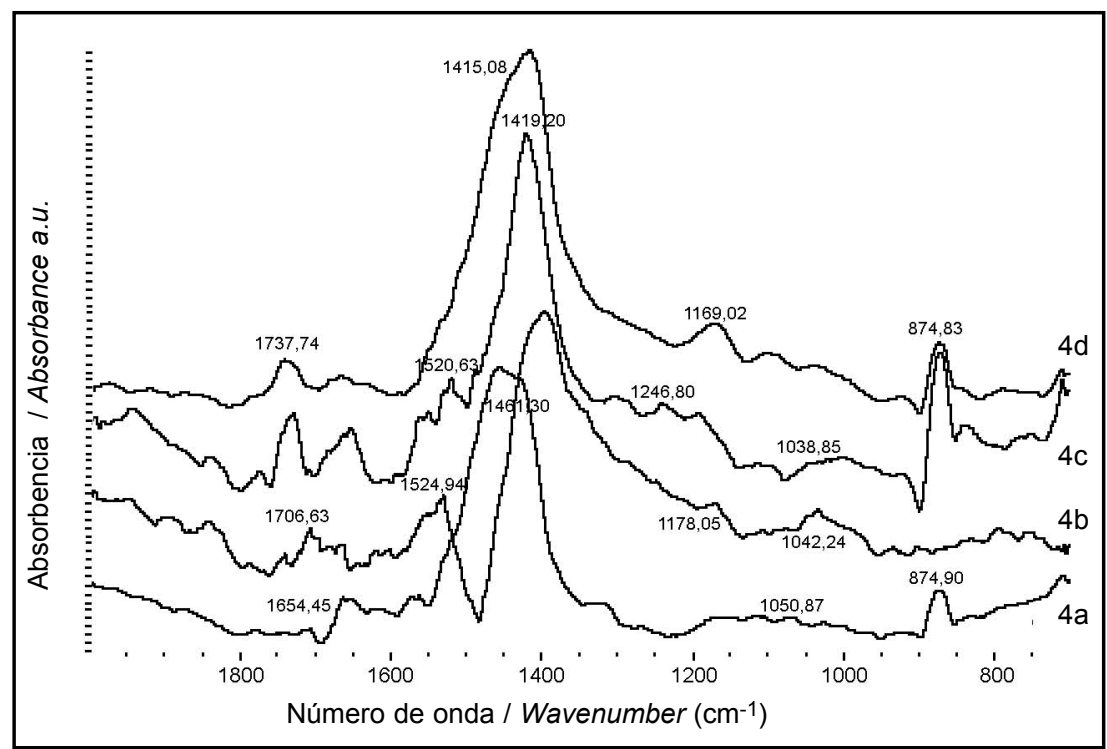

Figura 4. a), b), c) Espectros de infrarrojos correspondientes a los diferentes estratos de la muestra $1 ;$ d) Espectro de infrarrojos correspondiente al estrato superficial de la muestra 2. Figure 4. a), b), c) Infrared spectra from the layers in sample 1; d) infrared spectrum from the outermost layer in sample 2.

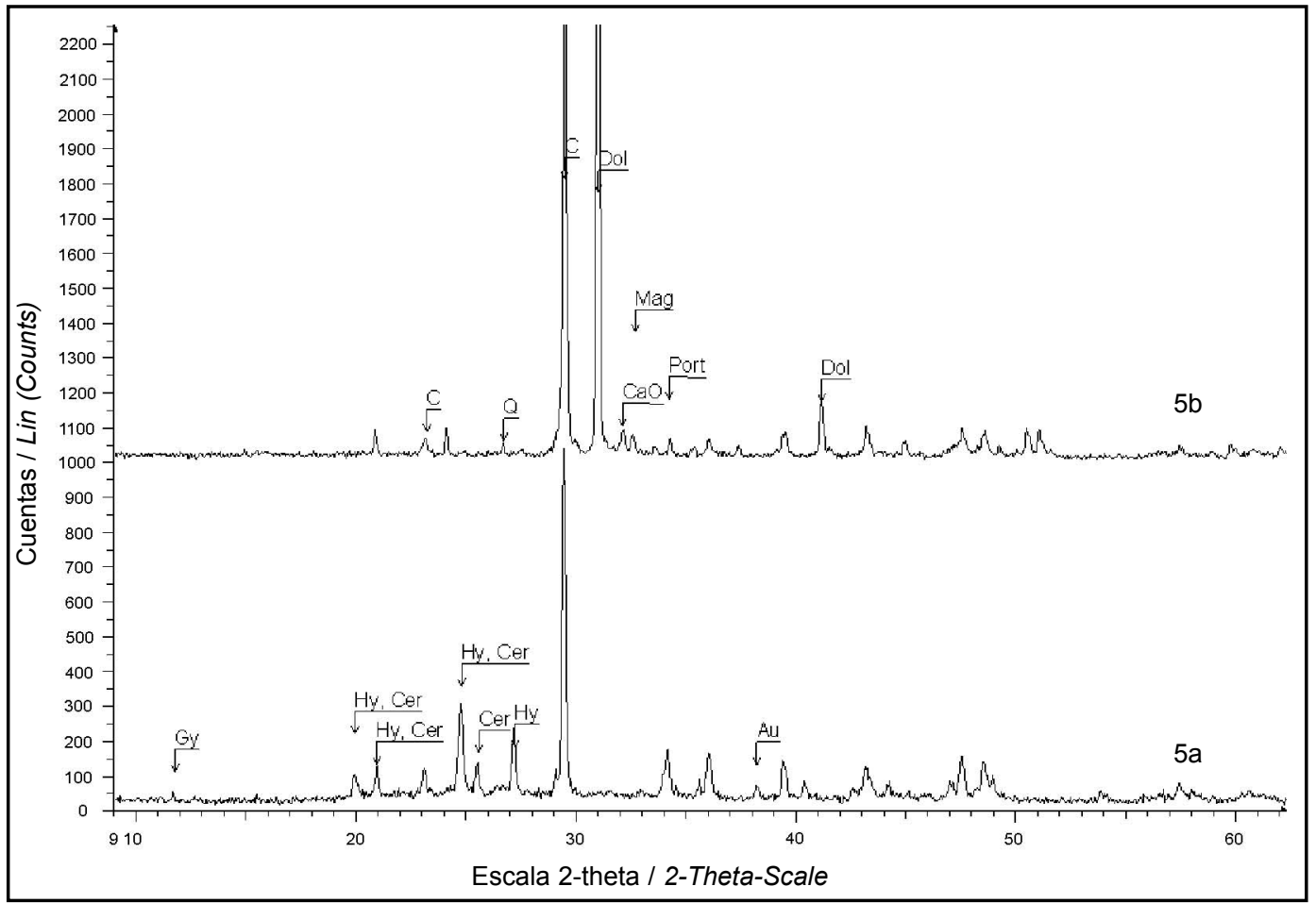

Figura 5. Diagramas de difracción de rayos $\mathrm{X}$ de: a) la muestra 2 completa (Gy=yeso, Cer=cerusita, $\mathrm{Hy}=$ hidrocerusita, $\mathrm{C}=$ calcita, $\mathrm{Au}=$ oro $)$; $\mathrm{b})$ una muestra de mortero $(\mathrm{C}=$ calcita, $\mathrm{Q}=$ cuarzo, $\mathrm{Dol}=$ dolomita, $\mathrm{Mag}=$ magnesita, $\mathrm{CaO}=\mathrm{cal}$, Port=portlandita).

Figure 5. X-ray diffraction diagrams from: a) sample 2 as a whole (Gy=gypsum, Cer=cerussite, $H y=$ hydrocerussite; $C=$ calcite, $A u=g o l d) ; b)$ a mortar sample ( $C=$ calcite, $Q=q u a r t z, D o l=$ dolomite, Mag=magnesite, $\mathrm{CaO}=$ lime, Port=portlandite).

\subsection{Colores azules y verdes}

Las muestras 4,5 y 6 se recogieron en el casetón número 33 , que contiene diferentes pigmentos y tintes de las hojas vegetales (Figura 1 b).

\subsection{Blue and green pigments}

Samples 4, 5 and 6 were taken from the plants depicted in coffer 33, which contained a number of pigments and dyes (Figure 1b). 
La Figura 2c muestra la estratigrafía de la muestra 4. Un estrato de color blanco aparece en la parte inferior, el cual está formado por calcita y yeso (Figura 6, espectro de IR, bandas de calcita a $1.461 \mathrm{~cm}^{-1}$ y $879 \mathrm{~cm}^{-1}$, y de yeso a $1.157 \mathrm{~cm}^{-1}$ ). Seguidamente se encuentra otro de color naranja, que contiene blanco de plomo y calcita; el análisis químico puntual sólo muestra la presencia de $\mathrm{Pb}$, $\mathrm{O}$ y $\mathrm{C}$, sugiriendo la presencia de minio (Figura 7a), que sería el compuesto responsable del color naranja. En las muestras 4 y 5 se observa un estrato de color azul, que se justificó por la presencia de azurita.

Por otra parte, un estrato de color verde, compuesto por malaquita, aparece en la muestra 6 (Figura 2d). El análisis químico muestra la presencia de $\mathrm{Cu}, \mathrm{C}$ y $\mathrm{O}$, además de $\mathrm{Pb}, \mathrm{O}$ y $\mathrm{Ca}$ (Figura $7 \mathrm{~b}$ ). Las medidas de color se realizaron in situ sobre aquellas zonas de la ornamentación del techo donde se conservan los colores azules y verdes. La determinación del color (por el fotocolorímetro) permitió la distinción entre la azurita $\left(L^{*}=69,65, \quad a *=-8,82, \quad b^{*}=-4,95\right)$ y la malaquita $\left(L^{*}=60,47, a^{*}=-8,45, b^{*}=8,48\right)$. La distinción es posible porque cuando estos dos pigmentos se muelen, la coloración de la azurita es azul verdosa y la de la malaquita es verde intensa $(7,18)$. La caracterización de estos minerales por difracción de rayos $X$ no fue posible debido a la baja proporción de los mismos en las muestras de pequeño tamaño que se tomaron. Por último, un estrato, constituido por blanco de plomo, calcita y pequeñas cantidades de yeso, aparece en la estratigrafía, de forma similar a lo descrito previamente en la muestra 2.

En algunos casos se detectaron compuestos de plomo en el estrato depositado antes del dorado, como fue mencionado por Pérez-Rodríguez y col. (19) y Durán y col. (20) en el estudio de las Puertas del Nacimiento y del Perdón de la Catedral de Sevilla.
The cross-section for sample 4 is shown in Figure 2c. The white bottom layer was found to contain calcite and gypsum (Figure 6, IR spectrum, calcite bands at 1461 $\mathrm{cm}^{-1}$ and $879 \mathrm{~cm}^{-1}$, and gypsum bands at $\left.1157 \mathrm{~cm}^{-1}\right)$. The following layer, predominantly orange, contained white lead and calcite. Chemical analysis showed $\mathrm{Pb}, \mathrm{O}$ and $C$ only, suggesting the presence of minium (red lead) (Figure 7a), which would be responsible for the orange hue. The presence of a blue layer in samples 4 and 5 was consistent with the presence of azurite.

The green layer observed in sample 6 (Figure 2d) consisted in malachite. Chemical analysis revealed the presence of $\mathrm{Cu}, \mathrm{C}$ and $\mathrm{O}$, in addition to $\mathrm{Pb}, \mathrm{O}$ and $\mathrm{Ca}$ (Figure $7 b$ ). The colours were measured in situ in the areas of the ceiling where the decoration contained green and blue hues. The results of these measurements with a photocolorimeter clearly distinguished the azurite $\left(L^{*}=69.65, a^{*}=-8.82, b^{*}=-4.95\right)$ from the malachite $\left(L^{*}=60.47, a^{*}=-8.45, b^{*}=8.48\right)$. Indeed, when these two pigments were ground, the azurite adopted a greenish blue tone, while malachite was deep green $(7,18)$. These minerals could not be characterized with $X$-ray diffraction techniques due to the small proportions present in the tiny samples taken from the ceiling. Lastly, the cross-section had a layer containing white lead, calcite and small amounts of gypsum, similar to the top layer described in sample 2.

In some of the samples, lead-based compounds were detected in the layer inmediately beneath the gilding, as mentioned befote by Pérez-Rodríguez et al. (19) and Durán et al. (20) in a study on the Nacimiento (Nativity) and Pardon (Forgiveness) entrances to Seville Cathedral.

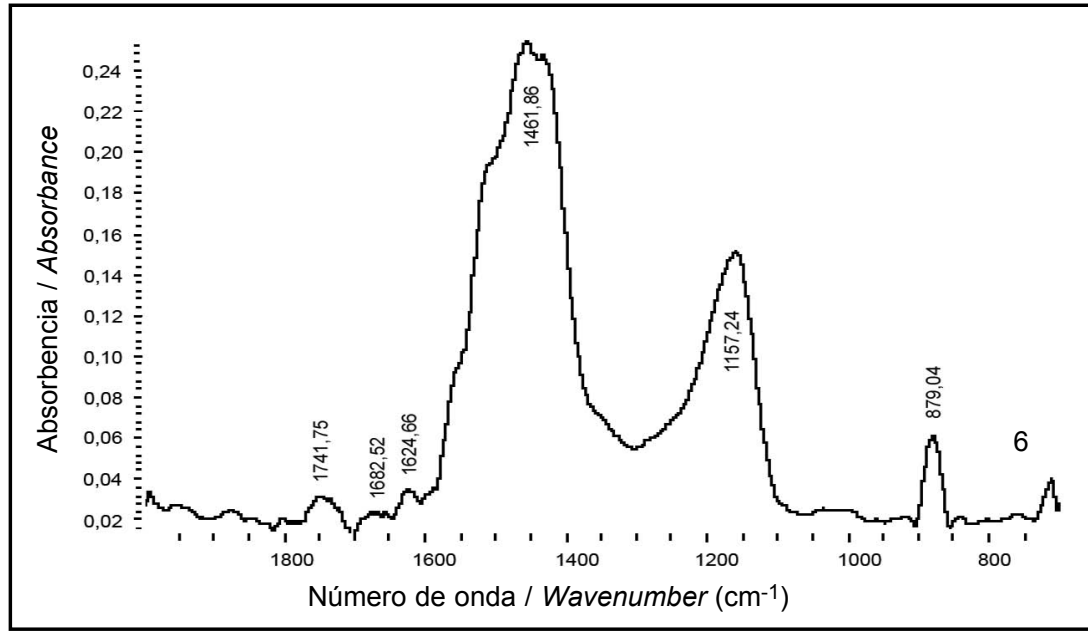

Figura 6. Espectro de infrarrojos del estrato inferior de la muestra 4. Figure 6. Infrared spectrum from the bottom layer in sample 4. 


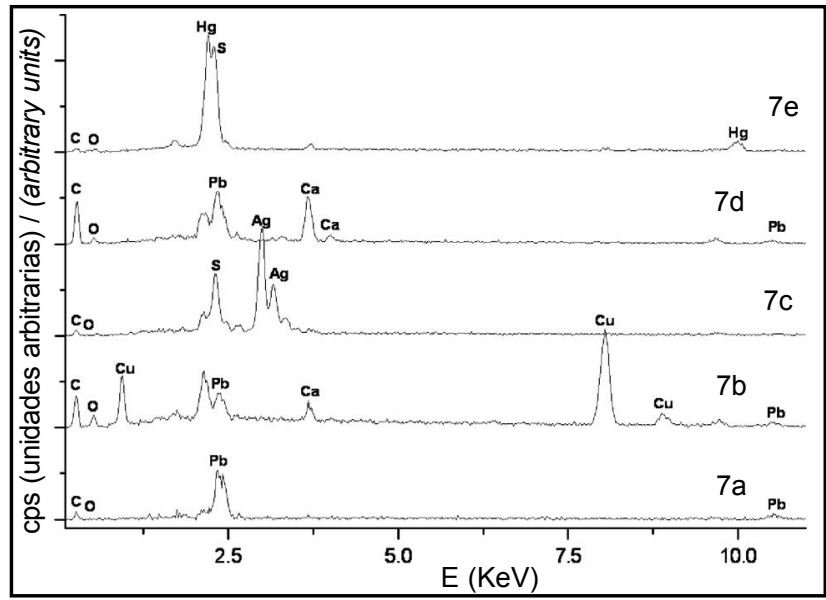

Figura 7. Análisis puntuales por energías dispersivas de rayos $X$ de: a) Estrato de color naranja de la muestra 4; b) Estrato de color verde de la muestra 6; c) Estrato intermedio de color plata de la muestra 8; d) Inscripciones de color negro de la muestra 16;

e) Estrato de color rojo de la muestra 9.

Figure 7. Spot energy dispersive $X$-ray analyses from: a) orange layer in sample $4 ; b$ ) green layer in sample 6; c) intermediate silver layer in sample 8; d) black inscriptions in sample 16; e) red layer in sample 9

\subsection{Muestras doradas con plata}

En la Figura 2e se observa la estratigrafía de la muestra 8 , tomada de la espada del rey Juan I. El estrato blanco situado en la parte inferior de la muestra está compuesto por calcita. Sobre este estrato se depositó una lámina de plata (Figura 7c, el espectro EDX muestra la presencia de Ag, S, C y O) u oro aleado con plata que fue cubierta a su vez por otro estrato de color marrón, que contiene blanco de plomo, óxidos de hierro y silicatos. Además, en este estrato se observa la presencia de pequeñas láminas de oro. Por último, se observa un estrato de color blanco, constituido por blanco de plomo, calcita y pequeñas cantidades de óxidos de hierro (análisis no mostrado). La plata fue uno de los metales mejor conocidos por los antiguos maestros, y se puede convertir fácilmente en hojas o láminas. En algunas pinturas antiguas, la plata fue usada como fondo de forma similar al oro. Los procedimientos de aplicación son los mismos en ambos metales. El uso de plata tratando de imitar al oro ha sido citado frecuentemente en la literatura. La plata se usó en pinturas de la Edad Media ocasionalmente, pero su tendencia a decolorar y oscurecer limitaron su uso (7). En los estratos de esta muestra que contenían plata, nosotros detectamos la presencia de sulfuros (Figura 7c, EDX: Ag, $\mathrm{S}, \mathrm{C}$ y O), por lo que la plata oscureció y perdió su brillo.

\subsection{Colores de la escritura}

Tres tipos de escritura aparecen en la ornamentación del techo: una negra (Figuras 1 b y $1 \mathrm{~d}$ ) y dos doradas (Figuras 1c y 1e). La estratigrafía correspondiente a una muestra de escritura negra se muestra en la Figura $2 f$

\subsection{Gilded samples with silver}

Figure 2e shows the cross-section of sample 8, taken from King John I's sword. The white layer at the bottom of the sample was observed to be made of calcite. The silver plating over this layer (Figure 7c, EDX spectrum showing the presence of $\mathrm{Ag}, \mathrm{S}, \mathrm{C}$ and $\mathrm{O}$ ) or a gold-silver alloy was in turn covered by a brown stratum containing white lead, iron oxides and silicates. Tiny pieces of gold leaf were also detected in this layer. Lastly, the top (white) layer contained white lead, calcite and small amounts of iron oxides (analysis not shown). Silver, one of the metals best known to sixteenth century goldsmiths, can readily be made into sheets or leaves. Like gold, silver was used as a background in some old paintings. The two metals were applied using the same methods. The use of silver in an attempt to imitate gold has been frequently reported in the literature. Due to its tendency to decolour and darken, however, it was used only occasionally in Medieval paintings (7). Sulfur, which causes silver to darken and dull, was detected in the layers containing studied here that contained the metal (Figure 7c, EDX: Ag, S, C and O).

\subsection{Colours in the inscriptions}

Three types of inscriptions can be found on the ceiling: one with black (Figures $1 b$ and $1 d$ ) and two with gilded lettering (Figures $1 \mathrm{c}$ and 1e). The cross-section of a sample taken from a black inscription (sample 16) is 
(muestra número 16). A un estrato blanco, compuesto por calcita, blanco de plomo, óxido de hierro y silicatos, le sigue un estrato negro, que contiene calcita, blanco de plomo y negro de humo. Para el análisis por SEM-EDX, todas las estratigrafías fueron cubiertas con similares cantidades de carbón. La gran intensidad del pico de carbono en el análisis por EDX (Figura 7d) sugiere la presencia del pigmento negro de humo.

Además, el negro de humo se describe normalmente como el pigmento empleado en la escritura de color negro en la literatura $(3,7,17,21)$; en estos casos, las muestras se cubrieron con oro y no con carbón para los análisis por SEM-EDX (figuras no mostradas).

En la Figura $2 \mathrm{~g}$ se observa la estratigrafía de la muestra de escritura dorada número 17 . Un estrato blanco, compuesto por calcita y blanco de plomo, aparece en el fondo de la muestra, al cual le sigue una capa de bol, que es cubierta por una lámina de oro. Un nuevo estrato blanco (con calcita, blanco de plomo y silicatos) aparece sobre esta lámina metálica, que es seguida por otra capa de bol y por último una segunda lámina de oro (Análisis no mostrado).

La diferencia entre estas muestras y las otras muestras doradas descritas previamente en este trabajo es que en el caso de las muestras procedentes de la escritura dorada, el oro no ha sido cubierto por una capa superficial de calcita y blanco de plomo.

\subsection{Otras muestras}

El análisis químico puntual de las pequeñas partículas de la muestra número 9 indica la presencia de $\mathrm{Hg}$ y $\mathrm{S}$, posiblemente debido a la presencia de bermellón (Figura 7e) de acuerdo con la literatura (22).

Las muestras $9,10,11,12,13$ y 14 se tomaron de la bóveda y mostraron una composición similar a las muestras doradas descritas previamente y a aquellas recogidas de la red que servía para la protección del techo (Figuras 1f y 2h). depicted in Figure 2f. A white layer, comprising calcite, white lead, iron oxide and silicates, served as a substrate for a black stratum containing calcite, white lead and carbon black. All the cross-sections were coated with similar amounts of carbon for SEM-EDX analysis. The intensity of the carbon signal in the EDX analysis (Figure 7d) suggested the presence of gas black.

Be it said that gas or carbon black is normally described in the literature as the pigment used in black inscriptions $(3,7,17,21)$. These samples were coated with gold instead of carbon for SEM-EDX analysis (results not shown).

Figure $2 g$ is a photograph of the cross-section of sample 17 , with gilded inscriptions. The bottom of the sample consisted in a white layer, with calcite and white lead, covered with a layer of bole, which served as a substrate for gold leaf. A second white stratum (with calcite, white lead and silicates), laid over this metallic plating, was followed by a layer of bole covered with gold leaf (analysis not shown).

The difference between these samples and the other gilded samples described earlier is that the gilded inscriptions had no over layer of calcite and white lead.

\subsection{Other samples}

Chemical analysis of the small particles in sample 9 revealed the presence of $\mathrm{Hg}$ and $\mathrm{S}$, possibly attributable to vermillion (Figure 7e) according to literature (22).

In samples, 9, 10, 11, 12, 13 and 14, taken from the vault, the composition was similar to the findings for the gilded samples described above and the samples taken from the protective net stretched under the ceiling (Figures $1 f$ and $2 h$ ).

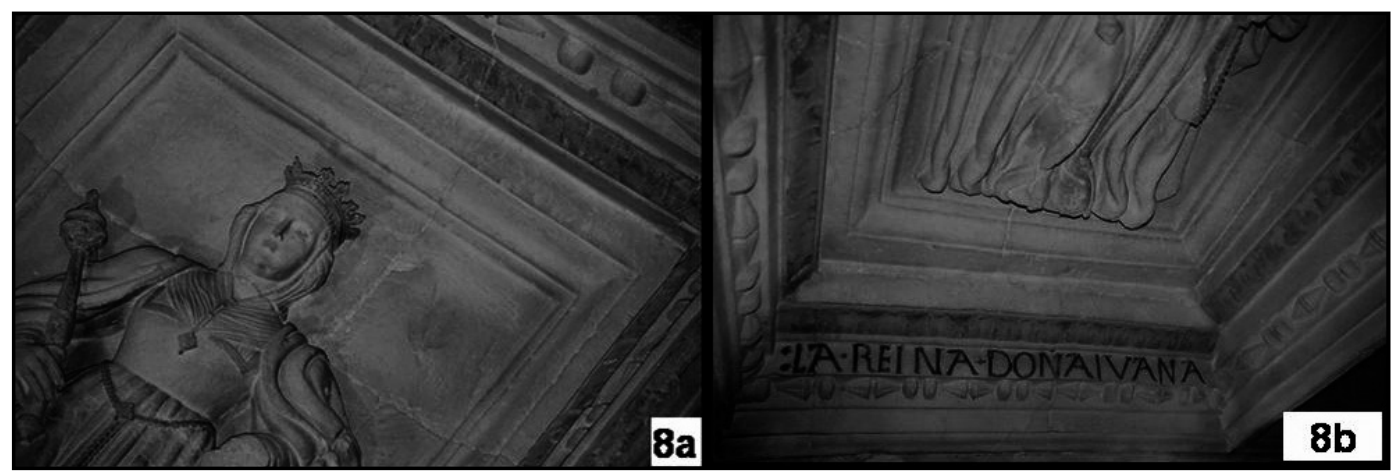

Figura 8. Fotografías: a), b) Recreación del casetón número 34 en su forma original y que corresponde a la reina Juana.

Figure 8. Photographs: a), b) Re-creation of coffer 34, depicting Queen Jane. 
El estudio por difracción de rayos $\mathrm{X}$ del mortero se muestra en la Figura $5 \mathrm{~b}$. Las fases presentes son dolomita (Dol) y calcita (Cal), además de cuarzo (Q) en baja proporción. Magnesita (Mag), portlandita (Port) y cal (CaO) son fases igualmente presentes.

\subsection{Hipótesis y propuesta de color a partir de la caracterización de los pigmentos}

Hemos medido algunas zonas de la ornamentación del techo. En la Tabla II, hemos considerado tres tipos específicos de valores. Los valores que aparecen en la tabla corresponden al color negro de la escritura, a los dorados de la escritura y la ornamentación, a los colores negros y dorados (localizados en zonas donde permanecen ambos tipos de letra), azules y verdes de las decoraciones vegetales $\mathrm{y}$, por último, los correspondientes a la piedra. Se indica el rango de valores de las tres componentes ( $\left.L^{*} a * b *\right)$ y la desviación estándar entre paréntesis $(\sigma)$. La propuesta de recreación de color se llevó a cabo en relación con las capas de pigmento encontradas. En las Figuras $8 \mathrm{a}$ y $8 b$, se muestra la propuesta de recreación de uno de los casetones, el número 34 que corresponde a la Reina Juana.
The X-ray diffraction pattern for the mortar shown in Figure $5 b$ contains signals attributed to dolomite (Dol), calcite (Cal) and small proportions of quartz (Q). Magnesite (Mag), portlandite (Port) and lime ( $\mathrm{CaO}$ ) were also detected.

\subsection{Hypotheses and proposals based on the results of pigment characterization}

The colours in certain zones of the ceiling were measured. Table II gives the values of CIE colour coordinates $L^{*} a^{*}$ and $b^{*}$ for the black inscriptions, gilded inscriptions and adornments, black and gilded inscriptions (in areas where both types persist), blues and greens in the plants and lastly, the stone itself. Both the range of values and the standard deviation $(\sigma)$ are shown for each parameter. The proposal for re-creating the colours was formulated on the basis of the layers of pigment found. Figures $8 \mathrm{a}$ and $8 \mathrm{~b}$ show the proposal for coffer 34, which contains a sculpture of Queen Jane.

Tabla 2 / Table 2

Mediciones de color de muestras de color azul, verde, doradas y negras, extraídas de la ornamentación del techo del Ayuntamiento. Colour measurements for blue, green, gilded and black samples taken from the decoration on the City Hall ceiling.

\begin{tabular}{|c|c|c|c|c|c|c|c|}
\hline \multicolumn{4}{|c|}{ Color dorado-negro / Gilding and black pigment } & \multicolumn{4}{|c|}{ Color negro / Black pigment } \\
\hline & L* & a* & b* & & L* & a* & b* \\
\hline $\begin{array}{c}1^{\mathrm{a}} \text { medida / } \\
\text { 1st measurement }\end{array}$ & $\begin{array}{l}57.06 \\
(3.27)\end{array}$ & $\begin{array}{c}4.17 \\
(0.04)\end{array}$ & $\begin{array}{l}14.80 \\
(0.09)\end{array}$ & $\begin{array}{c}1^{\mathrm{a}} \text { medida / } \\
\text { 1st measurement }\end{array}$ & $\begin{array}{l}47.07 \\
(0.02)\end{array}$ & $\begin{array}{c}1.01 \\
(0.00)\end{array}$ & $\begin{array}{c}4.46 \\
(0.01)\end{array}$ \\
\hline $\begin{array}{c}2^{\mathrm{a}} \text { medida/2nd } \\
\text { measurement }\end{array}$ & $\begin{array}{l}54.13 \\
(1.82)\end{array}$ & $\begin{array}{l}3.83 \\
(0.01)\end{array}$ & $\begin{array}{l}13.97 \\
\left(0^{\prime} 03\right)\end{array}$ & $\begin{array}{l}2^{\mathrm{a}} \text { medida/2nd } \\
\text { measurement }\end{array}$ & $\begin{array}{l}46.06 \\
(0.61)\end{array}$ & $\begin{array}{c}0.94 \\
(0.01)\end{array}$ & $\begin{array}{c}4.27 \\
(0.20)\end{array}$ \\
\hline $\begin{array}{l}3^{a} \text { medida/3rd } \\
\text { measurement }\end{array}$ & $\begin{array}{l}57.67 \\
(0.10)\end{array}$ & $\begin{array}{c}4.30 \\
(0.03)\end{array}$ & $\begin{array}{l}14.21 \\
(0.17)\end{array}$ & $\begin{array}{l}3^{a} \text { medida/3rd } \\
\text { measurement }\end{array}$ & $\begin{array}{l}46.74 \\
(0.96)\end{array}$ & $\begin{array}{c}0.98 \\
(0.01)\end{array}$ & $\begin{array}{c}4.25 \\
(0.06)\end{array}$ \\
\hline \multicolumn{4}{|c|}{ Color de la piedra / Stone-coloured pigment } & \multicolumn{4}{|c|}{ Color verde / Green pigment } \\
\hline & $\mathbf{L}^{*}$ & a* & b* & & L* & a* & b* \\
\hline $\begin{array}{c}1^{\mathrm{a}} \text { medida / } \\
\text { 1st measurement }\end{array}$ & $\begin{array}{l}68.47 \\
(0.55)\end{array}$ & $\begin{array}{l}3.90 \\
(0.01)\end{array}$ & $\begin{array}{l}15.63 \\
(0.12)\end{array}$ & $\begin{array}{c}1 \text { medida / } \\
\text { 1st measurement }\end{array}$ & $\begin{array}{l}59.65 \\
(0.12)\end{array}$ & $\begin{array}{l}-9.43 \\
(0.11)\end{array}$ & $\begin{array}{c}8.61 \\
(0.03)\end{array}$ \\
\hline $\begin{array}{c}2^{\mathrm{a}} \text { medida / } \\
\text { 2nd measurement }\end{array}$ & $\begin{array}{l}65.50 \\
(0.75)\end{array}$ & $\begin{array}{l}3.03 \\
(0.05)\end{array}$ & $\begin{array}{l}13.07 \\
(0.36)\end{array}$ & $\begin{array}{c}2^{\mathrm{a}} \text { medida / } \\
\text { 2nd measurement }\end{array}$ & $\begin{array}{l}60.47 \\
(0.62)\end{array}$ & $\begin{array}{l}-8.45 \\
(0.16)\end{array}$ & $\begin{array}{c}8.48 \\
(0.18)\end{array}$ \\
\hline $\begin{array}{c}3^{a} \text { medida / } \\
\text { 3rd measurement }\end{array}$ & $\begin{array}{l}67.53 \\
(2.96)\end{array}$ & $\begin{array}{l}3.40 \\
(0.13)\end{array}$ & $\begin{array}{l}13.67 \\
(0.12)\end{array}$ & $\begin{array}{c}3^{a} \text { medida / } \\
\text { 3rd measurement }\end{array}$ & $\begin{array}{l}59.92 \\
(1.08)\end{array}$ & $\begin{array}{l}-8.95 \\
(0.64)\end{array}$ & $\begin{array}{c}9.33 \\
(0.24)\end{array}$ \\
\hline \multicolumn{4}{|c|}{ Color dorado / Gilding } & \multicolumn{4}{|c|}{ Color azul / Blue pigment } \\
\hline & $\mathbf{L}^{*}$ & a* & b* & & L* & a* & $\mathbf{b}^{*}$ \\
\hline $\begin{array}{c}1^{\mathrm{a}} \text { medida / } \\
\text { 1st measurement }\end{array}$ & $\begin{array}{l}71.37 \\
(0.49)\end{array}$ & $\begin{array}{l}12.44 \\
(0.29)\end{array}$ & $\begin{array}{l}46.19 \\
(2.36)\end{array}$ & $\begin{array}{c}1^{\mathrm{a}} \text { medida / } \\
\text { 1st measurement }\end{array}$ & $\begin{array}{l}69.65 \\
(0.12)\end{array}$ & $\begin{array}{l}-8.82 \\
(0.05)\end{array}$ & $\begin{array}{l}-4.95 \\
(0.00)\end{array}$ \\
\hline $\begin{array}{c}2^{\mathrm{a}} \text { medida / } \\
\text { 2nd measurement }\end{array}$ & $\begin{array}{l}71.60 \\
(2.41)\end{array}$ & $\begin{array}{l}14.31 \\
(0.43)\end{array}$ & $\begin{array}{l}47.31 \\
(0.55)\end{array}$ & $\begin{array}{c}2^{\mathrm{a}} \text { medida / } \\
\text { 2nd measurement }\end{array}$ & $\begin{array}{l}69.66 \\
(0.44)\end{array}$ & $\begin{array}{l}-9.08 \\
(0.02)\end{array}$ & $\begin{array}{l}-5.00 \\
(0.01)\end{array}$ \\
\hline $\begin{array}{c}3^{a} \text { medida / } \\
\text { 3rd measurement }\end{array}$ & $\begin{array}{l}73.50 \\
(1.64)\end{array}$ & $\begin{array}{l}12.74 \\
(0.23)\end{array}$ & $\begin{array}{l}47.59 \\
(2.74)\end{array}$ & $\begin{array}{c}3^{\mathrm{a}} \text { medida / } \\
\text { 3rd measurement }\end{array}$ & $\begin{array}{l}70.09 \\
(0.94)\end{array}$ & $\begin{array}{l}-9.06 \\
(0.02)\end{array}$ & $\begin{array}{l}-5.04 \\
(0.00)\end{array}$ \\
\hline
\end{tabular}




\section{CONCLUSIONES}

La adhesión del oro a la piedra se produjo usando una capa de bol; con anterioridad la piedra se cubría con un estuco de calcita a la que seguía un estrato formado por el compuesto blanco de plomo. Las estratigrafías muestran que el proceso de dorado se llevó a cabo por duplicado, probablemente debido al deterioro de la lámina de oro original. En una de las muestras estudiadas, se usó plata, u oro aleado con plata. En ocasiones, compuestos de plomo aparecen en la lámina para adherir el oro a la superficie del techo.

El dorado se aplicó a los atributos de los reyes: coronas, cetros y espadas (en el caso de los hombres) y rosarios (en el caso de las mujeres).

Por otra parte, los dorados abundan en los altos relieves situados sobre las cornisas de las paredes, y también con esta técnica, se cubrieron túnicas y carteles. En el alto relieve con el Calvario, la cruz, la corona, los clavos, la mortaja y otros elementos pertenecientes al conjunto escultural y arquitectónico estaban también dorados, produciendo un efecto impresionante de suntuosidad.

La azurita y la malaquita se emplearon como pigmentos. Unas pocas partículas de bermellón también se observaron. La escritura en colores negro y dorado se obtuvo usando negro de humo y oro, respectivamente. Las estratigrafías estudiadas muestran que toda la ornamentación, excepto la zona de la escritura, permanecía cubierta por una capa de calcita y blanco de plomo. Además se detecta la presencia de yeso en la parte superficial, lo que fue justificado por la contaminación externa presente. El mortero de cal usado para la construcción de la sala está formado por calcita y dolomita, con una pequeña proporción de cuarzo.

El conjunto de bóvedas proporciona a la estancia un aspecto noble, preservando muchas de las muestras estudiadas, aunque a finales del siglo XIX, muchas fueron blanqueadas con una mezcla de cal y blanco de plomo. Además, para obtener un color similar a la piedra y homogeneizar la decoración en las paredes y el techo, se empleó una mezcla de silicatos y óxidos de hierro. De esta forma, las diferencias entre las piedras nuevas (pertenecientes a las últimas reformas) y las antiguas fueron eliminadas y se proporcionó un papel menos grandioso a la estancia por la eliminación de algunas partes doradas.

Las partes escritas no se blanquearon. Sin embargo, muchas zonas de la policromía permanecieron, las cuales pudimos estudiar, y que generalmente se doraron en el siglo XVI, a la manera de los grandes trabajos sobre piedra, como ocurrió en la Sala Capitular de la

\section{CONCLUSIONS}

A layer of bole was used to fix the gold leaf to the stone, which was previously prepared with one stucco layer each of calcite and white lead. The cross-sections showed that the ceiling was gilded twice, probably due to deterioration of the earlier layer. Silver or a gold-silver alloy was used in one of the samples studied. Leadbased compounds were occasionally observed in layers used to fix the gold leaf to the ceiling.

Gilding was used in the monarchs' attributes: crowns, sceptres and swords (the men) and rosary beads (the women).

The high reliefs on the cornices, tunics and heraldic mantles [inscriptions] were also gilded. In the high relief depicting the crucifixion, the gold leaf on the cross, crown, nails, shroud and other elements imbued this sculptural and architectural ensemble with a very lavish air.

Azurite and malachite were used as pigments. A few particles of vermillion were also observed. The black and golden hues in the inscriptions were achieved with carbon black and gold leaf, respectively. The crosssections showed that all the decoration, except the inscriptions, had been covered over with a layer of calcite and white lead. The gypsum detected on the outermost layer was regarded to be the result of exposure to the environment. The room was built with lime mortar made of calcite, dolomite and small amounts of quartz.

While many of the colours sampled have been preserved, lending the vaulted ensemble a noble aspect, in the nineteenth century many others were whitewashed with a mix of lime and white lead. This material also contained silicates and iron oxides to obtain a colour that would blend with the stone and harmonize the decoration on walls and ceiling. This eliminated the differences between the old stone and the new (laid in the latest reforms) and muted some of the room's grandiosity by covering part of the gilding.

The inscriptions were not whitewashed and the remains of the polychrome decoration are still visible and could be studied. Most of the adornments were gilded in the sixteenth century in much the same way as other major stone works, such as the Chapter 
Catedral de Sevilla, aunque más tarde, se volvió a dorar, como se ha observado en las estratigrafías preparadas y estudiadas en este trabajo.

Los resultados obtenidos en este artículo han contribuido a la recreación de colores en las esculturas y se han empleado para los procesos de restauración.
House in Seville Cathedral. Nonetheless, the conclusion drawn from the samples studied here was that they were later re-gilded.

The findings reported in this article were applied in the restoration process to re-create the colours on the sculptures.

\section{BIBLIOGRAFÍA / BIBLIOGRAPHY}

(1) Ortiz de Zúñiga, D.: Anales eclesiásticos de Sevilla (1677), t. IV, Madrid (1795), p. 73.

(2) Camon Aznar, J.: La arquitectura Plateresca, Madrid (1945), p. 150.

(3) Morales Martínez, A.: La obra renacentista del Ayuntamiento de Sevilla, Sevilla (1981), p. 225.

(4) Khandekar, N.: "Preparation of cross sections from easel paintings". Reviews in conservation, 4 (2003), pp. 52-64.

(5) Wachowiak, M. J.: "Efficient new methods for embedding paint and varnish samples for microscopy". JAIC 43 (2004), pp. 205-226.

(6) Herrera, L. K.; Cotte, M.; Jiménez de Haro, M. C.; Durán, A.; Justo, A.; Pérez-Rodríguez, J. L.: "Characterization of iron-oxide based pigments by synchrotron based micro X-ray diffraction". Applied Clay Science 42 (1-2) (2008), pp. 57-62.

(7) Gettens, R. J. and Stout, G. L.: "Painting Materials". Dover Publications, Inc., New York (1966), p. 333.

(8) Albella, J. M.; Cintas, A. M.; Miranda, T. y Serratosa, J. M.: "Introducción a la Ciencia de los Materiales", Consejo Superior de Investigaciones Científicas (1993), p. 749.

(9) Plesters, J.: "Cross-sections and chemical analysis of paint samples". Studies in conservation, 2 (1956), pp. 110-157. doi: $10.2307 / 1505000$

(10) Plesters, J.: "The preparation and study of paint cross-sections". The Museums Journal, 54 (4) (1954), pp. 97-101.

(11) Schreiner, M.; Frühman, B.; Jembrih-Simbürger, D. y Linke, R.: "X-rays in art and archaeology: an overview". Powder Diffraction, 19 (1) (2004), pp. 3-11. doi:10.1154/1.1649963

(12) Brindley, G. W. and Brown, G.: "Crystal Structures of clay minerals and their X-Ray Identification". Mineralogical Society Monograph, no 5 (1980), pp. 495-502.

(13) Alonso, M. L.: "Métodos instrumentales de análisis. Aplicación de la microscopia electrónica de barrido en el estudio de materiales inorgánicos". Técnicas de Diagnóstico aplicadas a la conservación de los bienes muebles, IAPH Sevilla (1996), pp. 135-142.

(14) Baker, M. T. and Von Endt, D. W.: "Use of FTIR microspectrometry in examination of artistic and historic works". Materials Research Society, V Bol. 123 (1988), pp. 71-76.

(15) Casadio, F. and Toniolo, L.: "The analysis of polychrome works of art: 40 years of infrared spectroscopic investigations". Journal of Cultural Heritage, 2 (2001), pp. 71-78. doi:10.1016/S1296-2074(01)01107-4

(16) Farmer, V. C.: "The Infrared Spectra of Minerals". Mineralogical Society, monograph 4 (1974), 539-600.

(17) Robador, M. D.: "Tradición y actualización en la protección de la arquitectura de piedra con finas capas de mortero de cal". RE no 31-32, Escuela de Arquitectura, Universidad de Navarra (2002), p. 250.

(18) www.handprint.com

(19) Pérez-Rodríguez, J. L.; Maqueda, C.; Justo, A.; Morillo, E.; Jiménez de Haro, M. C.: "Characterization of decayed ceramic sculptures decorating the Pardon portico of Seville cathedral, Spain". Applied Clay Science 9 (1994), pp. 211-223. doi:10.1016/01691317(94)90021-3

(20) Durán, A.; Pérez-Rodríguez, J. L.; Jiménez de Haro, M. C.; Herrera, L. K.; Justo, A.: "Degradation of gold and false golds used as gildings in the cultural Heritage of Andalusia, Spain". Journal of Cultural Heritage 9 (2008), pp. 184-188.

(21) Durán, A.; Herrera, L. K.; Robador, M. D.; Pérez-Rodríguez, J. L.: "Color Study of Mudejar Paintings of the pond found in the Palace of Reales Alcazares in Seville". Color Research and Application, vol. 32 (2007), Issue 6, pp. 489-495.

(22) Espejo Arias, T.; López-Montes, A.; García-Bueno, A.; Durán-Benito, A.; Blanc-García, R.: "A study about colourants in the Arabic manuscript Collection of the Sacromonte Abbey, Granada, Spain". Restaurator 29 (2) (2008), pp. 76-106. 